\title{
ANNIHILATOR CONCEPT AND ITS APPLICATION TO BEST APPROXIMATION THEORY
}

\author{
FERHAD HÜSEYÍNOĞLU NASÍBOV AND AHMET KAÇAR
}

\begin{abstract}
In Constructive Theory of Functions, two sections that look different but in fact have strong relations are very important:

1) Theory of best approximation of functions and,

2) Extremal problems for linear functionals that defined in different function classes.

Both of them studied independently started from the work [2] of P. L. Chebyshev and developed as systematic theories until the middle of 20th century. After that the relationship between these two theories has been realized and studied as connected theories. As a result, important findings for both problems obtained (S.M. Nikolskiy, M.G Kreyin, S. Ya Havinson, G.Ts.Tumarkin, W. Rogosinsky) ([1], [4], [5], [11-13]). "Duality" term coined for the relations between two problems such as these. In such duality relations, annihilator concept took place and played an important role. But no one studied or interested with the annihilator and its structure. F. H. Nasibov first one who studied and determined the annihilators' structure, and showed how to use it to solve the linear extremal problems $([6],[7],[8],[9],[10])$. In this paper, we will present our current findings about this topic.
\end{abstract}

\section{Definition of Class and Determining the Structure of Annihilator}

Let $E$ be a subset of $R_{1}=(-\infty,+\infty)$ and $\rho(x) \geq 0$ is a function (weighting function) defined on $E$. We use the notation for the function space of $\mathrm{f}(\mathrm{x})$ as $L_{2, \rho}(E)$ which satisfies the condition:

$$
\|f\|_{2, \rho}=\left\{\int_{E}|f(x)|^{2} \rho(x) d x\right\}^{1 / 2}<+\infty .
$$

We could also use $L_{2, \mu}(E)$ class which satisfies

$$
\|f\|_{2, \mu}=\left\{\int_{E}|f(x)|^{2} d \mu(x)\right\}^{1 / 2}<+\infty,
$$

Received by the editors June 15, 2009; Accepted: Sept. 18, 2009.

Key words and phrases. Space, Functional, Annihilator, Approximation, Constructive Theory of Function. 
where $\mu(x)$ satisfies $\int_{E} d \mu<+\infty$. It is explicit that $L_{2, \rho}(E) \subset L_{2, \mu}(E)$.

Now consider the system functions $\Phi=\left\{\varphi_{k}(t)\right\}_{0}^{\infty}$ that are orthonormal to $\rho(x)$ weighting function. In this case, each function $f(x) \in L_{2, \rho}(E)$ can be expand to the Fourier series:

$$
f(x) \sim \sum_{k=0}^{\infty} C_{k} \varphi_{k}(x) .
$$

This Fourier series converges to $\mathrm{f}(\mathrm{x})$ in the sense of $L_{2, \rho}(E)$ norm-metric, and satisfies the Parvesal formula

$$
\|f\|_{2, \mu}^{2}=\sum_{k=0}^{\infty}\left|C_{k}\right|^{2} .
$$

After this point, we will use notation $\Phi_{n}$ for polynomial set $p_{n}(t)=\sum_{k=0}^{n} a_{k} \varphi_{k}(t)$ $\left(a_{n} \neq 0\right)$, where $a_{k}(k=0,1,2, \ldots, n)$ are arbitrary constants:

$\Phi_{n}:=\left\{P_{n}(t)=\sum_{k=o}^{n} a_{k} \varphi_{k}(t) \quad\left(a_{n} \neq 0\right), a_{k}(k=0,1, \ldots, n)\right.$ are arbitrary constants $\}$

Problem 1. For $\Phi_{n} \subset L_{2, \rho}(E)$, define the structures of annihilator $\Phi_{n}^{\perp}$.

According to the definition $\Phi_{n}^{\perp}:=\left\{l \in\left(L_{2, \rho}\right)^{*}: \forall P_{n} \in \Phi_{n}, l\left(P_{n}\right)=0\right\}$. Now the problem becomes the defining the structure of functionals $l$, which satisfies the conditions mentioned above. On the other hand, we can represent each $l \in\left(L_{2, \rho}\right)^{*}$ linearly bounded (or continuous) functional as

$$
l(f)=\int_{E} f(t) \bar{g}(t) \rho(t) d t \equiv(f, g)
$$

and

$$
\|l\|=\sup _{f \in L_{2, \rho}^{1}(E)}|l(f)|=\|g\|_{2, \rho}
$$

formula is correct. In fact, we need to define the structure of functions $g(t) \in$ $L_{2, \rho}(E)$, which satisfies the condition

$$
l\left(P_{n}\right)=\int_{E} P_{n}(t) \bar{g}(t) \rho(t) d t=0 \quad\left(\forall P_{n} \in \Phi_{n}\right) .
$$

Let $a_{k}=a_{k}\left(P_{n}\right)$ is the arbitrary coefficients of $P_{n}(t) \in \Phi_{n}$ polynomial, and $C_{k}=C_{k}(g)$ is the Fourier coefficients of $g(t) \in L_{2, \rho}(E)$ according to $\Phi=\left\{\varphi_{k}(t)\right\}_{0}^{\infty}$ system. According to Parseval formula, we get

$$
l\left(P_{n}\right)=\int_{E} P_{n}(t) \bar{g}(t) \rho(t) d t=\sum_{k=0}^{n} a_{k} \overline{C_{k}} .
$$

From that we see $C_{k}=0(k=0,1,2, \ldots, n)$ so each $\left\{a_{k}\right\}_{0}^{n}\left(\forall P_{n} \in \Phi_{n}\right)$ satisfies the equation (1.7). This is the result we needed. (For example, if we have $c_{1} \neq 0$, then from $a_{1} c_{1}=0$ we have $a_{1}=0$. Since $a_{1}$ is arbitrary and if we choose $a_{1}=1$ then $\left.c_{1}=0\right)$. 
Hence we proved the theorem below which define the $\Phi_{n}^{\perp}$ annihilator.

Theorem 1. For subspace $\Phi_{n}$ of $L_{2, \rho}(E)$ annihilator $\Phi_{n}^{\perp}$ consists of functions $g(t) \in L_{2, \rho}(E)$ if and only if first $n+1$ Fourier coefficients of $g(t)$ (according to $\Phi$ system) satisfies the conditions

$$
C_{k}=C_{k}(g)=\int_{E} g(t) \overline{\varphi_{k}}(t) \rho(t) d t=0, \quad k=0,1,2, \ldots, n .
$$

\section{Applichtion to Best Approximation Problem}

Definition 1. Best approximation to element of $f \in L_{2, \rho}(E)$ by $P_{n}(t) \in \Phi_{n}$ polynomials is the

$$
E_{n}\left(f ; L_{2, \rho}\right)=\inf _{\mathrm{P}_{\mathrm{n}} \in \Phi_{\mathrm{n}}}\left\|f-\mathrm{P}_{\mathrm{n}}\right\|_{2, \rho} .
$$

There is an element on the $\Phi_{n}$ subspace which satisfies the equality

$$
E_{n}\left(f ; L_{2, \rho}\right)=\left\|f-\mathrm{P}_{\mathrm{n}}^{0}\right\|_{2, \rho}
$$

( $\Phi_{n}$ is finite dimensional). On the other hand, since $L_{2, \rho}(E)$ is strictly normed space, there is only one $P_{n}^{0}(t)$.

In the approximation theory, it is one of the difficult problems to find an element that gives the best approximation to a given element. That why it is important to learn the characteristics of given element (P. L. Chebyshev, S. N. Bernstein, A. N. Kolmogorov Theorems and others, [1], [3], [10-13]). For that purpose we want to remind the theorem below.

Theorem 2. (Zinger, [13]) $P_{n}^{0}(t) \in \Phi_{n}$ is the best approximation polynomial to $f(t) \in L_{2, \rho}$ if and only if for every $P_{n}(t) \in \Phi_{n}$ holds the conditions:

$$
\int_{E} P_{n}(t) \overline{\left[f(t)-P_{n}^{0}(t)\right]} \rho(t) d t=0 .
$$

It is apparent that Theorem 1 is equivalent to Theorem $2: \mathrm{T} 1 \Leftrightarrow \mathrm{T} 2$.

When we compare (1.7) and (2.3), we see $g(t)=\left[f(t)-P_{n}^{0}(t)\right] \in \Phi_{n}^{\perp}$.

Then, by Theorem $1, C_{k}\left(f-P_{n}^{0}\right)=0 \quad(k=0,1,2, \ldots, n)$ or

$$
C_{k}\left(P_{n}^{0}\right)=C_{k}(f) \quad(k=0,1,2, \ldots, n) .
$$

According to this, coefficients of polynomial which gives best approximation to $f(t) \in L_{2, \rho}$ on $L_{2, \rho}$ metric are the first $\mathrm{n}+1$ coefficient of Fourier Series of function f on the $\Phi=\left\{\varphi_{k}\right\}$ system. So we proved the A. Teopler Theorem which is below in the other method.

Theorem 3. (A. TEOPLER). Polinom of the best approximation to $f \in L_{2, \rho} \backslash \Phi_{n}$ on the $L_{2, \rho}$ metric (between $P_{n} \in \Phi_{n}$ polynomials) is

$$
P_{n}^{0}(t)=S_{n}(f, t)=\sum_{k=0}^{n} C_{k}(f) \varphi_{k}(t),
$$


which is the Fourier series partial sum order $n$ of $f(t)$ function according to $\Phi=\left\{\varphi_{k}\right\}$ system. Other than that one, best approximation value to $f(t)$ function with $P_{n} \in \Phi_{n}$ polynomials is defined by equality

$$
E_{n}(f)=\min _{\mathrm{P}_{\mathrm{n}} \in \Phi_{\mathrm{n}}}\left\|f-\mathrm{P}_{\mathrm{n}}\right\|_{L_{2, \rho}}=\left\{\sum_{k=n+1}^{\infty}\left|C_{k}(f)\right|^{2}\right\}^{1 / 2} .
$$

To validate what we said before, sufficiently to add investigation the following equalities:

$$
\begin{aligned}
\int_{E} \mid f(t)- & \left.P_{n}(t)\right|^{2} \rho(t) d t=\sum_{k=0}^{\infty}\left|C_{k}(f)-a_{k}\left(P_{n}\right)\right|^{2} \\
= & \sum_{k=0}^{n}\left|C_{k}(f)-a_{k}\left(P_{n}\right)\right|^{2}+\sum_{k=n+1}^{\infty}\left|C_{k}(f)-a_{k}\left(P_{n}\right)\right|^{2} \\
= & \sum_{k=0}^{n}\left|C_{k}(f)-a_{k}\left(P_{n}\right)\right|^{2}+\sum_{k=n+1}^{\infty}\left|C_{k}(f)\right|^{2}
\end{aligned}
$$

\section{Applichtion to Solution to an Extremal Problem}

Let $g_{0}(t) \in L_{2, \rho}$ be given. It defines a functional

$$
l_{0}(f)=\int_{E} f(t) \overline{g_{0}}(t) \rho(t) d t
$$

since $\Phi_{n} \subset L_{2, \rho}$

If we let $d \mu(t)=\rho(t) d t$, we get

$$
l_{0}\left(P_{n}\right)=\int_{E} P_{n}(t) \overline{g_{0}}(t) \rho(t) d t
$$

$$
l_{0}\left(P_{n}\right)=\int_{E} P_{n}(t) \overline{g_{0}}(t) d \mu(t) .
$$

Problem 2. Let's write $\Phi_{n, 1} \equiv\left\{P_{n} \in \Phi_{n}:\left\|P_{n}\right\|_{2, \mu}=\left(\int_{E}\left|P_{n}(t)\right|^{2} d \mu(t)\right)^{1 / 2} \leq 1\right\}$. Is to be found the norm

$$
\left\|l_{0}\right\|=\sup _{P_{n} \in \Phi_{n, 1}}\left|l_{0}\left(P_{n}\right)\right|=\sup _{P_{n} \in \Phi_{n, 1}}\left|\int_{E} P_{n}(t) \overline{g_{0}}(t) d \mu(t)\right| .
$$

The solution of this problem is based on the following duality principle:

Theorem $4([5])$. For every linear functional $l_{0}$ that defined on an subspace of $F$ of any normed linear space $X$,

$$
\sup _{x \in F_{1}}\left|l_{0}(x)\right|=\inf _{l \in F^{\perp}}\left|l_{0}-l\right|
$$

where $l_{0} \in F^{*}, F_{1}$ is a unit sphere on $\mathrm{F}$. 
Since $X=L_{2, \rho}, F=\Phi_{n}, F_{1}=\Phi_{n, 1}$ and $l_{0} \leftrightarrow g_{0}(t) \in L_{2, \rho}$, instead of (3.5) we get

$$
\sup _{P_{n} \in \Phi_{n, 1}}\left|\int_{E} P_{n}(t) \overline{g_{0}}(t) d \mu(t)\right|=\inf _{g \in \Phi^{\perp}}\left\|g_{0}-g\right\|_{2, \mu} .
$$

By Parseval formula, we can rearrange (3.6) as

$$
\begin{aligned}
\sup _{a_{k}\left(P_{n}\right)}\left|\sum_{k=0}^{n} a_{k}\left(P_{n}\right) C_{k}\left(g_{0}\right)\right| & =\inf _{C_{k}(g)}\left(\sum_{k=0}^{\infty}\left|C_{k}\left(g_{0}\right)-C_{k}(g)\right|^{2}\right)^{1 / 2} \\
& =\inf _{C_{k}(g)}\left\{\sum_{k=0}^{n}\left|C_{k}\left(g_{0}\right)\right|^{2}+\sum_{k=n+1}^{\infty}\left|C_{k}\left(g_{0}\right)-C_{k}(g)\right|^{2}\right\}^{1 / 2} \\
& =\left\{\sum_{k=0}^{n}\left|C_{k}\left(g_{0}\right)\right|^{2}+\inf _{C_{k}(g)} \sum_{k=n+1}^{\infty}\left|C_{k}\left(g_{0}\right)-C_{k}(g)\right|^{2}\right\}^{1 / 2} \\
& =\left\{\sum_{k=0}^{n}\left|C_{k}\left(g_{0}\right)\right|^{2}\right\}^{1 / 2} .
\end{aligned}
$$

For $k \geq n+1$, requirement $C_{k}\left(g^{*}\right)=C_{k}(g)$ must hold. At this point, $g^{*}$ is the extremal element for the right side of (3.6). On the other hand, $\Phi_{n}$ is finite dimensional. According to this, there is a $P_{n}^{0}(t) \in \Phi_{n, 1}$ polynomial that gives sup (extremal) to the left side of the (3.6). Hence the theorem below is true.

Theorem 5. There is a unique $P_{n}^{0}(t) \in \Phi_{n, 1}$ polynomial that supplies condition $\left\|l_{0}\right\|=\left|l_{0}\left(P_{n}^{0}\right)\right|$ of problem (3.6) and of left hand side of (3.4). As well as

$$
\begin{aligned}
\max _{P_{n} \in \Phi_{n, 1}}\left|\int_{E} P_{n}(t) \overline{g_{0}}(t) d \mu(t)\right| & =\max _{a_{k}}\left|\sum_{k=0}^{n} a_{k}\left(P_{n}\right) C_{k}\left(g_{0}\right)\right| \\
& =\inf _{g \in \Phi_{n}^{\perp}}\left(\sum_{k=0}^{\infty}\left|C_{k}\left(g_{0}\right)-C_{k}(g)\right|^{2}\right)^{1 / 2} \\
& =\left(\sum_{k=0}^{n}\left|C_{k}\left(g_{0}\right)\right|^{2}\right)^{1 / 2}
\end{aligned}
$$

duality relations are true. We get $\max$ for such a $P_{n}^{0}(t) \in \Phi_{n, 1}$ polynomial that its coefficients can be computed if and only if

$$
\left.\begin{array}{l}
a_{k}^{0}=\frac{e^{i \alpha}}{\lambda} \frac{\left|C_{k}\left(g_{0}\right)\right|^{2}}{C_{k}\left(g_{0}\right)}=e^{i \alpha} \overline{C_{k}\left(g_{0}\right)} \quad(k=0,1,2, \ldots, n) \\
\lambda=\left(\sum_{k=0}^{n}\left|C_{k}\left(g_{0}\right)\right|^{2}\right)^{1 / 2}
\end{array}\right\}
$$

where $C_{k}\left(g_{0}\right)$ s are the Fourier coefficients of $g_{0}(t)$ function according to $\Phi=\left\{\varphi_{k}\right\}$ system. 
Validity of (3.8) can be seen from the operations below. Let $P_{n}^{0}(t)=\sum_{k=0}^{n} a_{k}^{0} \varphi_{k}(t)$ be an extremal polynomial. Then $\int_{E} P_{n}(t) \overline{g_{0}}(t) d \mu(t)=\sum_{k=0}^{n} a_{k}^{0} \overline{\left[C_{k}\left(g_{0}\right)-C_{k}\left(g^{*}\right)\right]}$ , where $g^{*}(t) \in \Phi_{n, 1}$ function gives inf to the right side of (3.6). Because of, we have

$$
\begin{gathered}
\left|\int_{E} P_{n}(t) \overline{g_{0}}(t) d \mu(t)\right|=\left|\sum_{k=0}^{n} a_{k}^{0} \overline{\left[C_{k}\left(g_{0}\right)-C_{k}\left(g^{*}\right)\right]}\right| \\
\leq\left(\sum_{k=0}^{n}\left|a_{k}^{0}\right|^{2}\right)^{\frac{1}{2}}\left(\sum_{k=0}^{n}\left|C_{k}\left(g_{0}\right)-C_{k}\left(g^{*}\right)\right|^{2}\right)^{1 / 2} .
\end{gathered}
$$

Consequently,

$$
\left|\int_{E} P_{n}(t) \overline{g_{0}}(t) d \mu(t)\right| \leq\left(\sum_{k=0}^{n}\left|C_{k}\left(g_{0}\right)-C_{k}\left(g^{*}\right)\right|^{2}\right)^{1 / 2} .
$$

Since $P_{n}^{0}(t)$ and $g^{*}(t)$ are extremal elements, inequalities here must be converted to equalities. This is true if and only if formulas of (3.9) true. Because $C_{k}\left(g^{*}\right)=0$ $(k=0,1,2, \ldots, n)$.

\section{Applichtion to Solution to Another Extremal Problem}

Duality relations, which we will consider in this section is: If an element $\omega(t) \in X \backslash F$ is given, then

$$
\max _{l \in F_{1}^{\perp}}|l(\omega)|=\inf _{\varphi \in F}\|\omega-\varphi\|_{E}
$$

is true and $F_{1}^{\perp}=\left\{l \in F^{\perp}:\|l\| \leq 1\right\}$.

In our case

$$
\max _{g \in \Phi_{n, 1}^{\perp}}\left|\int_{E} \omega(t) \bar{g}(t) d \mu(t)\right|=\inf _{P_{n} \in \Phi_{n}}\left\|\omega-P_{n}\right\|_{2, \mu} .
$$

Now, suppose that

$$
\begin{gathered}
\omega(t) \sim \sum_{k=0}^{\infty} C_{k}(\omega) \varphi_{k}(t), \\
P_{n}(t)=\sum_{k=0}^{n} a_{k} \varphi_{k}(t)
\end{gathered}
$$


and if we take $g(t) \sim \sum_{k=0}^{\infty} C_{k}(g) \varphi_{k}(t), C_{k}\left(g_{0}\right)=0 \quad(k=0,1,2, \ldots, n)$, (means $\left.g \in \Phi_{n, 1}^{\perp}\right)$ we get

$$
\begin{aligned}
\max _{C_{k}(g)}\left|\sum_{k=n+1}^{\infty} C_{k}(\omega) \cdot \overline{C_{k}}(g)\right| & =\min _{a_{k}}\left\{\sum_{k=0}^{\infty}\left|C_{k}(\omega)-a_{k}\right|^{2}\right\}^{1 / 2} \\
& =\min _{a_{k}}\left\{\sum_{k=0}^{n}\left|C_{k}(\omega)-a_{k}\right|^{2}+\sum_{k=n+1}^{\infty}\left|C_{k}(\omega)\right|^{2}\right\}^{1 / 2} \\
& =\left\{\sum_{k=n+1}^{\infty}\left|C_{k}(\omega)\right|^{2}\right\}^{1 / 2} .
\end{aligned}
$$

Thus we proved the theorem below.

Theorem 6. Duality relations below is true

$$
\begin{aligned}
\|l\|=\max _{g \in \Phi_{n, 1}^{\perp}}\left|\int_{E} \omega(t) \bar{g}(t) d \mu(t)\right| & =\left\{\sum_{k=n+1}^{\infty}\left|C_{k}(\omega)\right|^{2}\right\}^{1 / 2} \\
& =\left\{\|\omega\|_{2, \mu}^{2}-\sum_{k=0}^{n}\left|C_{k}(\omega)\right|^{2}\right\}^{1 / 2}
\end{aligned}
$$

There is a unique $g \in \Phi_{n, 1}^{\perp}$ that gives maximum of the left hand side.

ÖZET: Konstrüktif fonksiyonlar teorisinde birbirinden farklı gibi görünen aslında ise aralarında sıkı bir bağlantı olan iki bölüm çok önemlidir:

1) Fonksiyonların en iyi yaklaşım teorisi,

2) Herhangi bir fonksiyon sinıfında tanımlı lineer fonksiyoneller için ekstremal problemler.

Her ikisi de P. L. Chebyshev'in temel oluşturan [2] çalışmasından başlayarak XX. yüzyılın ortalarına kadar serbest olarak geliştirildi ve kapsamlı, sistemli teoriler haline yükselebildi. Bu tarihten sonra da bu konular arasında mevcut olan ilişki fark edildi. Bu konular birbirleri ile irtibat halinde, paralel olarak, araştırılmaya başlandı. Sonuçta her iki problemde önemli sonuçlar elde edildi (S.M. Nikolskiy, M.G Kreyin, S. Ya Havinson, G.Ts.Tumarkin, W. Rogosinsky) ([1], [4], [5], [11-13]). Böyle iki türden problemler arasında oluşturulan bağlantılara ikili (duality) ilişki adı verildi. Bu tür ikili ilişkilerde de sıfırlayan kavramı yer aldı ve önemli rol oynadı. Fakat bu tip bağlantılarda sıfırlayanlarılar incelenmedi, yapısıyla fazla ilgilenilmedi.

Bu konuyda ilk olarak F. H. Nasibov i bazı fonksiyon sinıfları için sıfırlayanların yapısını belirledi ve lineer problemlerin çözümünde 
uygulanabileceğini gösterdi $([6],[7],[8],[9],[10])$. Bu makalede bu konuda elde ettiğimiz neticelerden bazıları sunulacaktır.

\section{REFERENCES}

[1] Akhiyeser, N. I., Theory of Approximation, (1965), M. pp 1-408; Dover Publications, New York.

[2] Chebyshev, P. L., "The theory of mechanisms known under the name of parallelograms", Complete Collected Works, Vol 2, M2, M.-4, (1947).

[3] İbragimov, I. I., Teoriya Priblijeniya Tselımi Funktsiyami, 1979, Baku, İzd. "ELM" NAN Azerbaijan Republic, 1-468, (In Russian).

[4] Khavinson, S.Ya., On an Extremal Problems of the Theory of Analytic Function, Usp Math. Nauk, V4, N4, Moscow, (1949), 158-159.

[5] Khavinson, S.Ya \& Çatskaya, Ye, Ş., Dvoystvenniye Sootnoşeniya i Kriterii Elementov Nailuçsego Priblijeniya, MİSİ, Moscow, (1976), (In Russian).

[6] Nasibov, F. G., Annulyator Klassa $W_{\sigma, z}$ u Nekotoryye Primeneniya, VİNITI, No 1671-82, Dep. (1982), 1-11, Moscow, (In Russian).

[7] Nasibov, F. G., Description of Annihilator of one Class of Entire Functions of Finite SemiOrder and Some Applications, İzv. VUZ SSSR, MATEMATİKA, V. 30, N 2, (1986), 29-33.

[8] Nasibov, F. G., Extremal Problems in Classes of Entire Functions Bounded on the Real Axis, İzv. VUZ SSSR, V44, N10, (2000), 45-52, Allerton Press, New York.

[9] Nasibov, F. G., K Extremalnım Problemam v Klassakh Tselıkh Funktsiy, Dokl. NAN Azerbaijan Republic, V62, N5-6, (2006), 26-32, (In Russian).

[10] Nasibov, F. G., Extremalnıye Zadachi v Klassakh Tsehkh Funktsiy, , İzd. "ELM" NAN Azerbaijan Republic, (1998), 1-298, Baku, (In Russian).

[11] Natanson, I. P., Konstruktivnaya Teoriya Funktsiy, 1949, Moskova, 1-688. (In Russian)

[12] Timan, A. F., Teoriya Priblijeniya Funktsiy Deystvitelnogo Peremenogo, 1960, Moscow, (In Russian). (Theory of Approximation of Functions of a Real Variable, Dover Publ., INC, New York, 1963).

[13] Zinger, I., Best Approximation in Normed Linear Spaces by Elements of Linear Subspaces, 1970, Berlin, Springer.

Current address: Ferhad HÜSEYÍNOĞLU NASÍBOV: Kastamonu University, Faculty of Arts and Science, Dept. of Physics, Kastamonu, TURKEY., Ahmet KAÇAR: Kastamonu University, Education Faculty, Elementary Education Department, Kastamonu, TURKEY,

E-mail address: fnasibov@kastamonu.edu.tr, akacar@kastamonu.edu.tr 